\title{
Horizontal and vertical distribution of larvae of Pacific bluefin tuna Thunnus orientalis in patches entrained in mesoscale eddies
}

\author{
Keisuke Satoh* \\ National Research Institute of Far Seas Fisheries, 5-7-1 Orido, Shimizu-ku, Shizuoka City, Shizuoka 424-8633, Japan
}

\begin{abstract}
Nine high density larval populations (patches) of Pacific bluefin tuna Thunnus orientalis were detected and 7 patches were tracked with reference buoys for 28 to $171 \mathrm{~h}$ in the northwestern Pacific Ocean in May-June 2004 to 2008. Buoy trajectories and surface current velocities and directions measured by acoustic Doppler current profiler data showed close agreement. Growth rates for the sampled larvae (3.0 to $9.9 \mathrm{~mm}$ standard length [SL], 4 to $17 \mathrm{~d}$ after hatch), estimated by the daily modes of SL, correspond to growth rates estimated from otolith daily ring analysis. These results indicate that the same populations were sampled by tracking the buoy on almost all the sampling days. At fine- $(100 \mathrm{~s}$ of $\mathrm{m}$ to $\mathrm{km})$ and mid-scale observations ( 15 to $30 \mathrm{~km}$ range), patches consisted of a number of cohorts which had different distributions within the patch. The larval spatial structure was studied using variograms. At the fine scale, age-specific sills, ranges and spatial dependence of patches were similar; at the mid scale, these indexes showed stability during the trackings. Horizontally, larvae formed patches within an approximate $10 \mathrm{~km}$ range and advected together during the larval stage. Larvae were only distributed in the mixed layer and diel vertical movement was not clearly observed. Patches were entrained in mesoscale eddies ( 100 to $500 \mathrm{~km}$ diameter) which propagated westward. Such mesoscale eddies are known to coalesce with the Kuroshio current. The spawning area and the recruitment fishing grounds are thereby linked by the Kuroshio. Results suggest that cohorts have a stable spatial structure after fertilization (i.e. during advection, while entrained in mesoscale eddies). Therefore, the positional relationship between spawning events and mesoscale eddies is concluded to be important for the recruitment process.
\end{abstract}

KEY WORDS: Stability of spatial structure $\cdot$ Horizontal distribution $\cdot$ Vertical distribution $\cdot$ Mesoscale eddy $\cdot$ Kuroshio $\cdot$ Larval patch $\cdot$ Thunnus orientalis $\cdot$ Northwestern Pacific Ocean

Resale or republication not permitted without written consent of the publisher

\section{INTRODUCTION}

Pacific bluefin tuna Thunnus orientalis is one of the most important fisheries species in Japan. Their spawning grounds are located off the coast of the Nansei Islands, southern Japan, where spawning occurs from April to June; spawning occurs in the Sea of Japan in August (Yabe et al. 1966, Okiyama 1974). Bluefin tuna larvae hatch after about $24 \mathrm{~h}$ at $26.5^{\circ} \mathrm{C}$ (Miyashita 2002), at a standard length (SL) of about $3.0 \mathrm{~mm}$. They grow to nearly $10 \mathrm{~mm}$ SL over $20 \mathrm{~d}$ and are then referred to as early juveniles. After 2 or 3 mo they grow to about $30 \mathrm{~cm}$ SL and recruit to the troll fishery along the southern coast of Japan, located north of the spawning grounds (see Fig. 1). Yamada et al. (2006) have reported that recruitment of Pacific bluefin tuna fluctuates considerably: up to a 6 -fold interannual variability. Large annual fluctuations in year-class strength of marine fishes can be caused by cumulative effects of subtle differences in the mortality rate or growth rate through early life stages (Houde 1987). In order to understand recruitment variability, it is necessary to study the factors that affect the mortality rate and growth rate variability during the planktonic early life stages. The determinants of mortality rate during early life stages are considered to be predation, starvation and deleterious oceanographic 
conditions that may advect larvae into unsuitable environments for recruitment (Houde 1987).

Many studies have focused on the effect of migration on the survival processes of fish larvae (e.g. Davis et al. 1991, Dower et al. 2002, Pepin et al. 2002). The linkage between physical and biological processes affecting fish larvae have been suggested to be most readily investigated by following the development of identifiable cohorts of individuals (Heath 1992). Such patch studies are expected to allow a clearer understanding of the impact of environmental variability over several days, a time scale relevant to the dynamics of organisms such as larval fish (Dower et al. 2002). In a recent study, Satoh et al. (2008) tracked populations of bluefin tuna larvae in high densities (hereafter 'patches') using Lagrangian drifters and collected larvae repeatedly from the same patches.

The spawning area off the Nansei Islands is characterized by the Kuroshio current and mesoscale eddies. The Kuroshio is located northwest of the spawning ground and flows in the direction of the Pacific coast of the Japan Islands. The mesoscale eddies are composed of cyclonic and anticyclonic eddies with diameters varying from 100 to $500 \mathrm{~km}$ and a temporal duration of about $80 \mathrm{~d}$ at latitudes from 27 to $30^{\circ} \mathrm{N}$. The typical maximum surface velocity associated with these eddies are 15 to $20 \mathrm{~cm} \mathrm{~s}^{-1}$ (Ebuchi \& Hanawa 2000). These eddies propagate westward at about 7 to $10 \mathrm{~cm} \mathrm{~s}^{-1}$ in the Kuroshio recirculation region and some coalesce with the Kuroshio (Ebuchi \& Hanawa 2001).

The aims of the present study were to (1) describe the fine- to large-scale spatial distribution of larval patches of Pacific bluefin tuna; (2) understand the changes in spatial structure during the larval stage; (3) understand the relationship between horizontal distributions and environmental conditions during the larval stage; (4) describe the differences in the vertical distribution between night and day; and (5) investigate the role of the Kuroshio current and mesoscale eddies in the recruitment of bluefin tuna.

\section{MATERIALS AND METHODS}

Field sampling. Sampling was carried out in the northwestern Pacific Ocean off the Nansei Islands from 2004 to 2008 each year in May or from May to June (Table 1, Fig. 1). In order to detect a larval patch of Pacific bluefin tuna, we conducted trial tows which consisted of surface horizontal tows for 5 or $10 \mathrm{~min}$ using a $2 \mathrm{~m}$ diameter ring net (mesh aperture $0.335 \mathrm{~mm}$ ). For the trial tows, we selected areas where the sea surface temperature, which has previously been determined as an important factor for high density tuna larval distributions (Nishikawa et al. 1985), was approximately $26^{\circ} \mathrm{C}$. We conducted the trial tows about every 8 to $9 \mathrm{~km}$ and detected 9 patches, which were numbered serially (Table 1, Fig. 1). Seven of these 9 patches were marked by a drifter composed of a GPS radio buoy (Taiyo Musen) and an $8 \mathrm{~m}$ 'holey sock' drogue centered at a depth of $12 \mathrm{~m}$ intended to track the current in the mixed layer which was 20 to $50 \mathrm{~m}$ depth. The positions of buoys were typically detected every 1 to $3 \mathrm{~h}$ during tracking and buoy velocities and directions were calculated between adjacent positions and time records. The distance between the reference buoy and each sampling station was calculated through a combination of parallel, middle latitude and Mercator's sailing.

After the deployment of the buoy, surface tows in all years (2004-2008), oblique tows in 2006, 2007 and 2008, and specific layer horizontal tows in 2005 were conducted relative to the buoy. Except for Patch 3 (2005 cruise), the first sampling position of each night was determined as the reference buoy position immediately before the start time of sampling (around 20:00 h); positions of successive sampling stations during the night (from 20:00 $\mathrm{h}$ to the next pre-dawn, $\sim 05: 00 \mathrm{~h}$ ) were located radially about $5 \mathrm{~km}$ from the first sampling station. The number of sampling stations per night was, in general, 7 for the 2006 and earlier cruises and 5 for 2007 and 2008. In the 2005 cruise

Table 1. Temperature and salinity averaged from 0 to $10 \mathrm{~m}$ depth, and tracking duration, date, start and end time and position. Patches 5 and 6 were not tracked

\begin{tabular}{|c|c|c|c|c|c|c|c|c|c|c|c|}
\hline \multirow[t]{2}{*}{ Patch } & \multirow{2}{*}{$\begin{array}{c}\text { Temperature } \\
\left({ }^{\circ} \mathrm{C}\right)\end{array}$} & \multirow{2}{*}{ Salinity } & \multirow{2}{*}{$\begin{array}{c}\text { Duration } \\
\text { (h) }\end{array}$} & \multicolumn{4}{|c|}{ — Tracking start (detection) } & \multicolumn{4}{|c|}{ - Tracking end - } \\
\hline & & & & Date & Time (h) & Latitude & Longitude & Date & Time $(\mathrm{h})$ & Latitude & Longitude \\
\hline 1 & 28.6 & 34.5 & 54 & 2004.05 .15 & $23: 37$ & $22^{\circ} 25.568^{\prime} \mathrm{N}$ & $124^{\circ} 34.694^{\prime} \mathrm{E}$ & 2004.05 .18 & $05: 48$ & $21^{\circ} 57.908^{\prime} \mathrm{N}$ & $124^{\circ} 46.185^{\prime} \mathrm{E}$ \\
\hline 2 & 25.8 & 34.6 & 28 & 2004.06 .01 & $23: 52$ & $26^{\circ} 07.599^{\prime} \mathrm{N}$ & $129^{\circ} 07.920^{\prime} \mathrm{E}$ & 2004.06 .03 & $03: 55$ & $26^{\circ} 07.139^{\prime} \mathrm{N}$ & $129^{\circ} 20.813^{\prime} \mathrm{E}$ \\
\hline 3 & 27.6 & 34.4 & 77 & 2005.06 .02 & $04: 47$ & $24^{\circ} 35.095^{\prime} \mathrm{N}$ & $126^{\circ} 00.030^{\prime} \mathrm{E}$ & 2005.06 .05 & 09:40 & $25^{\circ} 09.925^{\prime} \mathrm{N}$ & $126^{\circ} 40.373^{\prime} \mathrm{E}$ \\
\hline 4 & 27.4 & 34.2 & 171 & 2006.05 .22 & 02:01 & $23^{\circ} 55.495^{\prime} \mathrm{N}$ & $124^{\circ} 46.611^{\prime} \mathrm{E}$ & 2006.05 .29 & 05:08 & $22^{\circ} 33.514^{\prime} \mathrm{N}$ & $125^{\circ} 20.008^{\prime} \mathrm{E}$ \\
\hline 5 & 26.5 & 34.1 & - & 2006.06 .13 & $19: 56$ & $24^{\circ} 30.298^{\prime} \mathrm{N}$ & $127^{\circ} 39.843^{\prime} \mathrm{E}$ & & & & \\
\hline 6 & 26.4 & 34.1 & - & 2006.06 .14 & 03:04 & $24^{\circ} 29.627^{\prime} \mathrm{N}$ & $128^{\circ} 19.420^{\prime} \mathrm{E}$ & & & & \\
\hline 7 & 26.6 & 34.8 & 48 & 2007.05 .17 & 03:45 & $22^{\circ} 57.260^{\prime} \mathrm{N}$ & $124^{\circ} 52.101^{\prime} \mathrm{E}$ & 2007.05 .19 & 03:49 & $23^{\circ} 17.639^{\prime} \mathrm{N}$ & $125^{\circ} 32.774^{\prime} \mathrm{E}$ \\
\hline 8 & 29.0 & 34.4 & 50 & 2007.05 .28 & $00: 54$ & $25^{\circ} 15.011^{\prime} \mathrm{N}$ & $124^{\circ} 00.002^{\prime} \mathrm{E}$ & 2007.05 .30 & 03:16 & $25^{\circ} 11.378^{\prime} \mathrm{N}$ & $125^{\circ} 58.647^{\prime} \mathrm{E}$ \\
\hline 9 & 25.3 & 34.4 & 69 & 2008.05 .24 & 03:06 & $24^{\circ} 21.564^{\prime} \mathrm{N}$ & $127^{\circ} 00.434^{\prime} \mathrm{E}$ & 2008.05 .27 & 00:02 & $23^{\circ} 55.079^{\prime} \mathrm{N}$ & $127^{\circ} 36.004^{\prime} \mathrm{E}$ \\
\hline
\end{tabular}




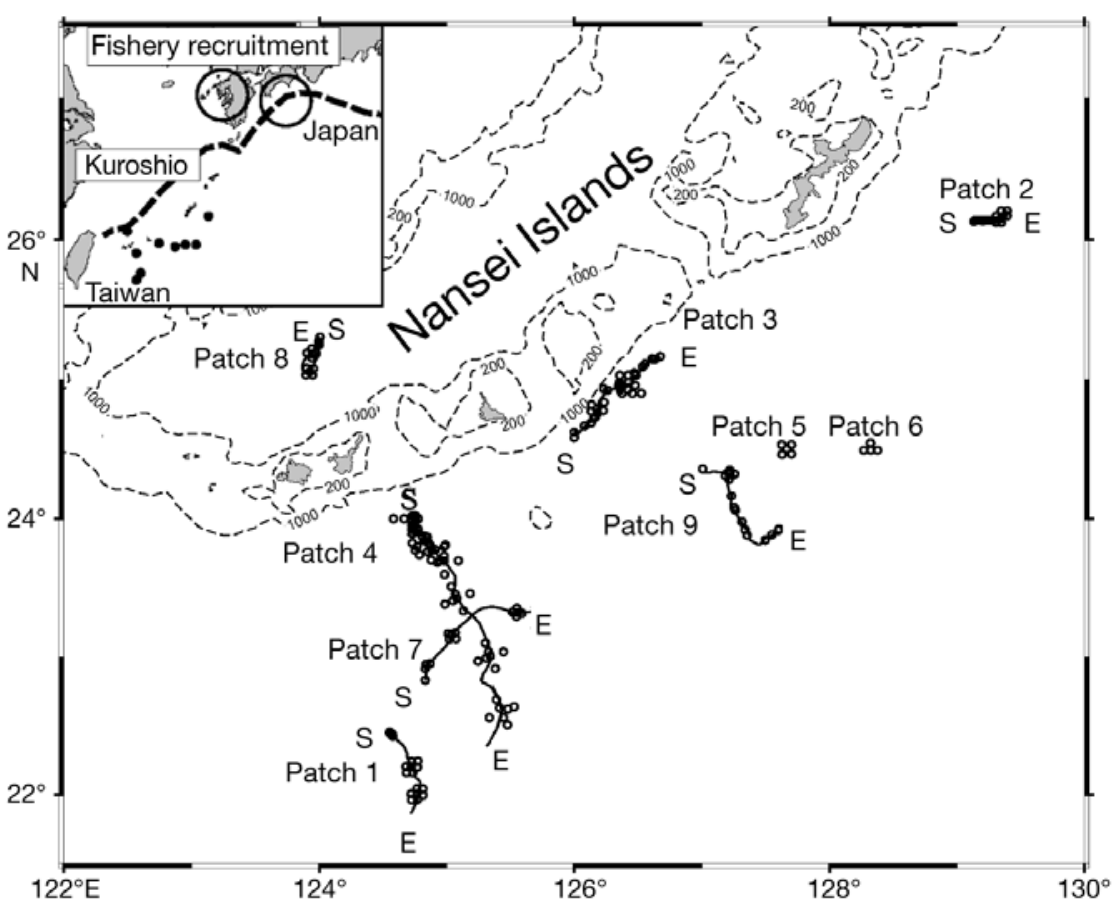

Fig. 1. Study region off the coast of the Nansei Islands, Japan, showing the 9 study sites and patch numbers, with the sampling stations (open circles), buoy trajectories (solid lines) and tracking start (S) and end position (E). Dashed lines represent 200 and $1000 \mathrm{~m}$ depth contours. Inset — dashed line: Kuroshio Current; large open circles: fishing grounds to which bluefin tuna recruit; solid circles: location of patches equipped with calibrated flow meters. The density of the larvae was calculated from the water volumes filtered. Once on deck, each tow net was washed down. The samples collected with the $2 \mathrm{~m}$ ring net were preserved in $99.5 \%$ ethanol and the ethanol was replaced within $24 \mathrm{~h}$. In order to assess the density (no. $\mathrm{l}^{-1}$ ) of small copepods and copepod nauplii (hereafter copepods), which are considered as the main food materials for the bluefin tuna larvae (2.3 to $14.6 \mathrm{~mm} \mathrm{SL}$, Uotani et al. 1990), water samples of 11 in 2004 and $10 \mathrm{l}$ in 2005 were taken from the sea surface using a bucket, and from 2006 (except for June 2006) to 2007, the samples of the $30 \mathrm{~cm}$ ring net were filtrated through a $0.335 \mathrm{~mm}$ mesh. In 2004, in order to describe the fine-scale distribution over 100s of $\mathrm{m}$ to $\mathrm{km}$ in Patches 1 and 2, a transect of $20 \times 5$ min surface tows was conducted at night (00:00 to 04:00 h) for both patches, and resulted in sampling lines of 12.1 and $12.7 \mathrm{~km}$ for Patches 1 and 2, respectively. In June 2006, for the purpose of understanding the large-scale distribution of the number of patches, surface tows at 30

(Patch 3), the sampling times and area per day were intensive (11 or 15 stations over a $15 \mathrm{~km}$ range), because it included daytime sampling and the position of each sampling station was determined radially 3 to $8 \mathrm{~km}$ from the position of the reference buoy at the last sampling. The reference buoy always migrated during sampling, thus the buoy was located at the origin for purposes of graphical exposition in sampling; sampling stations around the buoy were located systematically for Patch 3, and for other patches the position of stations tended to be located over the track of the buoy (Fig. 1).

For the surface horizontal tows, we used a $2 \mathrm{~m}$ diameter ring net which was towed at 1.5 knots for 5 or $10 \mathrm{~min}$. For the oblique tows, we used a $2 \mathrm{~m}$ ring net which was towed from the bottom of the mixed layer at approximately $50 \mathrm{~m}$ depth to the surface at a ship speed of $1.5 \mathrm{knots}$ and a line speed of $0.6 \mathrm{~m} \mathrm{~s}^{-1}$. In 2006, 2007 and 2008, a $30 \mathrm{~cm}$ diameter ring (mesh aperture $0.05 \mathrm{~mm}$ ) was fixed within the mouth of the $2 \mathrm{~m}$ ring. Specific layer horizontal tows were conducted by a multiple opening/closing net and environmental sampling system (MOCNESS) (mesh size $0.335 \mathrm{~mm}$ ) (Wiebe et al. 1976) which was towed at 2.5 knots for $5 \mathrm{~min}$ at 10, 20, 50 and $100 \mathrm{~m}$ depth. The nets were stations and oblique tows at 23 stations were carried out every $\sim 36$ to $40 \mathrm{~km}$ within a $\sim 150 \mathrm{~km}$ diameter.

At each sampling station, temperature and salinity were observed by casts up to maximum of $500 \mathrm{~m}$ depth with a CTD probe (SBE911, Sea-Bird Electronics). Sea currents around the buoy were measured by an acoustic Doppler current profiler (ADCP) mounted on the bottom of the ship ( $38.4 \mathrm{kHz}, \mathrm{RD}$ Instruments). Data from the ADCP were recorded in $8 \mathrm{~m}$ depth bins (first bin $=13$ to $21 \mathrm{~m}$ ) and the bias of ship direction between the estimation from the gyro and the real heading of the ship was corrected according to the methods described in Kamoshida et al. (2004).

Laboratory treatment. The tuna larvae were identified to species based on pigmentation according to the criteria detailed in Nishikawa (1985). Standard length (SL; tip of the snout to tip of the notochord, or the hypural crease in post-flexion larvae) of each fixed tuna larva was measured to the nearest $0.1 \mathrm{~mm}$ with a micrometer. The SLs of larvae were corrected for the effect of shrinkage due to fixation (Satoh et al. 2008). Daily ages (days after hatch [DAH]) were determined by the number of increments of otolith plus 4 according to the method given in Itoh et al. (2000) and Tanaka et al. (2006). Densities of larvae were corrected for SL of 
larvae and sampling hour if not otherwise specified (Somerton \& Kobayashi 1989, Satoh et al. 2008). Zooplankton species were identified to the lowest possible taxonomic group using the criteria of Chihara \& Murano (1997). The number of copepod individuals was counted under an inverted microscope and is represented as density (no. $\mathrm{l}^{-1}$ ).

Data analysis. An ordinary kriging method was used to interpolate density values between the sampling stations so that the bluefin larval population size of each cohort on each tracking day could be estimated (Rivoirard et al. 2000, Li et al. 2007).

For the preprocessing of the ordinary kriging, spatial structural analyses, which aim at describing and modeling the spatial structure using variogram, were conducted. When the larval densities of each station are available, the experimental variogram $\gamma^{*}(h)$ is calculated by the following equation:

$$
\gamma^{*}(h)=0.5 \frac{1}{\mathrm{~N}(h)} \sum_{\mathrm{x}_{\mathrm{i}}-\mathrm{x}_{\mathrm{j}} \sim h}\left[z\left(\mathrm{x}_{\mathrm{i}}\right)-z\left(\mathrm{x}_{\mathrm{j}}\right)\right]^{2}
$$

where $\mathrm{N}(h)$ is the number of pairs of stations $\left(\mathrm{x}_{\mathrm{i}}, \mathrm{x}_{\mathrm{j}}\right)$, separated by the distance $h$ in the summation; and $z\left(\mathrm{x}_{\mathrm{i}}\right)-z\left(\mathrm{x}_{\mathrm{j}}\right)$ is the difference in larval density between pairs of stations $\left(x_{i}, x_{j}\right)$, separated by the distance $h$, which is used to categorize the distance between a pair of stations. Usually the lag spacing approximates the sample distance (Rivoirard et al. 2000); however, the sample distance was different according to the sampling strategy mentioned above. An experimental variogram was calculated for each cohort on each tracking day and each towing method (surface and oblique tows). A lag spacing of $0.5 \mathrm{~km}$ was used for Patches 1 and 2 on Tracking day $0,2.0 \mathrm{~km}$ was used for the other experimental variograms at the mid scale and $8 \mathrm{~km}$ (surface) and $15 \mathrm{~km}$ (oblique) were used for Patches 5 and 6 at the large scale. The sample variance equals the means of the variograms values, weighted by the number of pairs (Rivoirard et al. 2000). Thus the order of magnitude of a variogram is that of the sample variance. The magnitude of larval density usually differed among patch, DAH and tracking day. Therefore, in order to allow ease of comparison among variograms with different levels of larval densities, the variograms were standardized to their sample variances (divided by the variance).

A variogram model was fitted to the experimental variogram. The value of the variograms may be small when the distance between stations is small, and it may be bounded at a certain distance where there is no correlation between larval densities of a pair of stations. This distance is called the range and the bounded value of the variograms is the sill. The range is the area unit for a station with a high correlation. The nugget effect, the jump at the origin of the vari- ograms, reflects the microscale variation of the variable. The obvious nugget effect might suggest the presence of dense larval aggregation within the spatial scale of 1 plankton net path ( 250 to $500 \mathrm{~m})$. Three theoretical variogram models are commonly used in the modeling: (1) spherical model: variogram = nugget + sill [(3 distance/2 range) - (distance/2 range $\left.)^{3}\right]$, when distance $(\mathrm{km}$ between a pair of stations) $\leq$ range; variogram = nugget + sill, when distance $>$ range $;(2)$ exponential model: variogram $=$ nugget + sill $[1-\exp (-$ dis tance/range)], when distance $>0$; variogram $=0$, when distance $=0$; and (3) Gaussian model: variogram = nugget + sill $\left[1-\exp (- \text { distance/range })^{2}\right]$. For the fitting, all the sample points were used to fit the models, except for Patches 1 and 2 on Tracking day 0 and Patch 3, where only the sample points with less than half the maximum $h$ were used. In addition, Journel \& Huijbregts (1978) recommended the use of more than 30 pairs of stations in each lag to avoid instability in the experimental variogram; however, the number of pairs was less than this value in Patches 4, 7, 8 and 9. The appropriate model was selected according to the criterion which minimizes the goodness-of-fit (GOF) in consideration of weight, $w(h)$, which is proportional to the number of pairs used to compute $\gamma^{*}(h)$ (Rivoirard et al. 2000).

$$
\mathrm{GOF}=\frac{\sum_{h} w(h)\left[\gamma(h)-\gamma^{*}(h)\right]^{2}}{\sum_{h} w(h)\left[\gamma^{*}(h)\right]^{2}}
$$

where $\gamma(h)$ is the predicted variogram by the model at distance $h$, and $\gamma^{*}(h)$ is the experimental variogram.

Using the theoretical variogram model with best fit, ordinary kriging predictions were computed as

$$
\hat{\mathrm{Z}}\left(s_{0}\right)=\sum_{i=1}^{N} w_{i} \mathrm{Z}\left(s_{i}\right)
$$

where $\hat{\mathrm{Z}}\left(s_{0}\right)$ is the estimate of larval density at unsampled position $s_{0}$ and $w_{i}$ is the weight attributed sample larval density $\mathrm{Z}\left(s_{i}\right)$. The $\mathrm{R}$ gstat module (R Development Core Team 2009) was used for fitting and the ordinary kriging.

Sea surface height and geostrophic current. Sea surface height ( $\mathrm{SSH})$ is expressed as the difference from the geoid height. The SSH data used in the present study were obtained from the Japan Meteorological Agency (http://goos.kishou.go.jp/) every $5 \mathrm{~d}$ for each year of interest. SSH data were derived from satellite altimeter data (TOPEX/POSEIDON and Jason 1 altimeters) and determined for $0.25^{\circ}$ latitudinal and longitudinal squares in the seas between $28^{\circ} \mathrm{S}$ and $56^{\circ} \mathrm{N}$ from $118.75^{\circ} \mathrm{E}$ to $79.5^{\circ} \mathrm{W}$ since January 2003 (Kuragano \& Shibata 1997, Kuragano \& Kamachi 2000, 2003). The geostrophic currents were calculated based on the SSH data. 


\section{RESULTS}

\section{Tracking and sea surface current}

We detected 9 larval patches and tracked 7 of these with reference buoys over a duration ranging from 28 to $171 \mathrm{~h}$; the remaining 2 patches (Patches 5 and 6) were not tracked because they were sampled for the purpose of understanding the large-scale distribution of the number of patches. Sea surface temperature and salinity averaged from 0 to $10 \mathrm{~m}$ depth at the start position of each tracking ranged from 25.3 to $29.0^{\circ} \mathrm{C}$ and salinity 34.1 to 34.8 , respectively (Table 1). Ranges of velocities and directions of sea surface currents during trackings measured from ADCP and buoy trajectories are shown in Fig. S1 (available online at www.int-res. com/articles/suppl/m404p227_app.pdf). The buoy trajectories were in close accordance with the direction of geostrophic currents derived from SSH except for Patches 2 and 8, for which the direction showed the opposite and no correlation, respectively (Fig. S2). The modes of SL distributions of larvae in Patches 4, 7, 8 and 9 of each tracking day indicated daily increments of 0.2 to $0.9 \mathrm{~mm} \mathrm{~d}^{-1}$ (Fig. 2). In addition, the daily changes of mode of length frequency of 0.2 to $0.6 \mathrm{~mm}$ $\mathrm{d}^{-1}$ of Patches 1, 2 and 3 have already been reported (Satoh et al. 2008). The age-specific growth rate, derived from analysis of daily otolith rings, ranged from 0.25 to $0.78 \mathrm{~mm} \mathrm{~d}^{-1}$ (Table 2).

\section{Horizontal distribution}

The basic statistics and characteristics of theoretical variogram models are given in Tables S1 \& S2 for each patch on each tracking day by larval age for surface tow samples.

Fine-scale distribution

The transect tows were carried out 20 times for both Patches 1 and 2 on Tracking day 0. Both patches consisted of larvae that ranged in age from 5 to $12 \mathrm{DAH}$ and the dominant ages for each patch were 6 to 9 and 6 to $12 \mathrm{DAH}$, respectively (Table S1). During the 20 times we sampled, the reference buoy moved continuously, and the larval population would be expected to move together with the buoy. Therefore, it is appropriate to represent the horizontal position of the sampling station in the patch as the position relative to the reference buoy. Thus, the relative position of each station was calculated, and then (based on their relative position) the distances of adjacent stations were calculated (Fig. 3). Sampling was conducted at night (00:00 to 04:00 h) for both patches, and the interval between each sampling line was 12.1 and $12.7 \mathrm{~km}$ for Patch 1 and 2, respectively (Fig. 3). Along the sampling lines, the distributions of the 6,9 and $12 \mathrm{DAH}$ larvae suggested that each cohort was distributed continuously
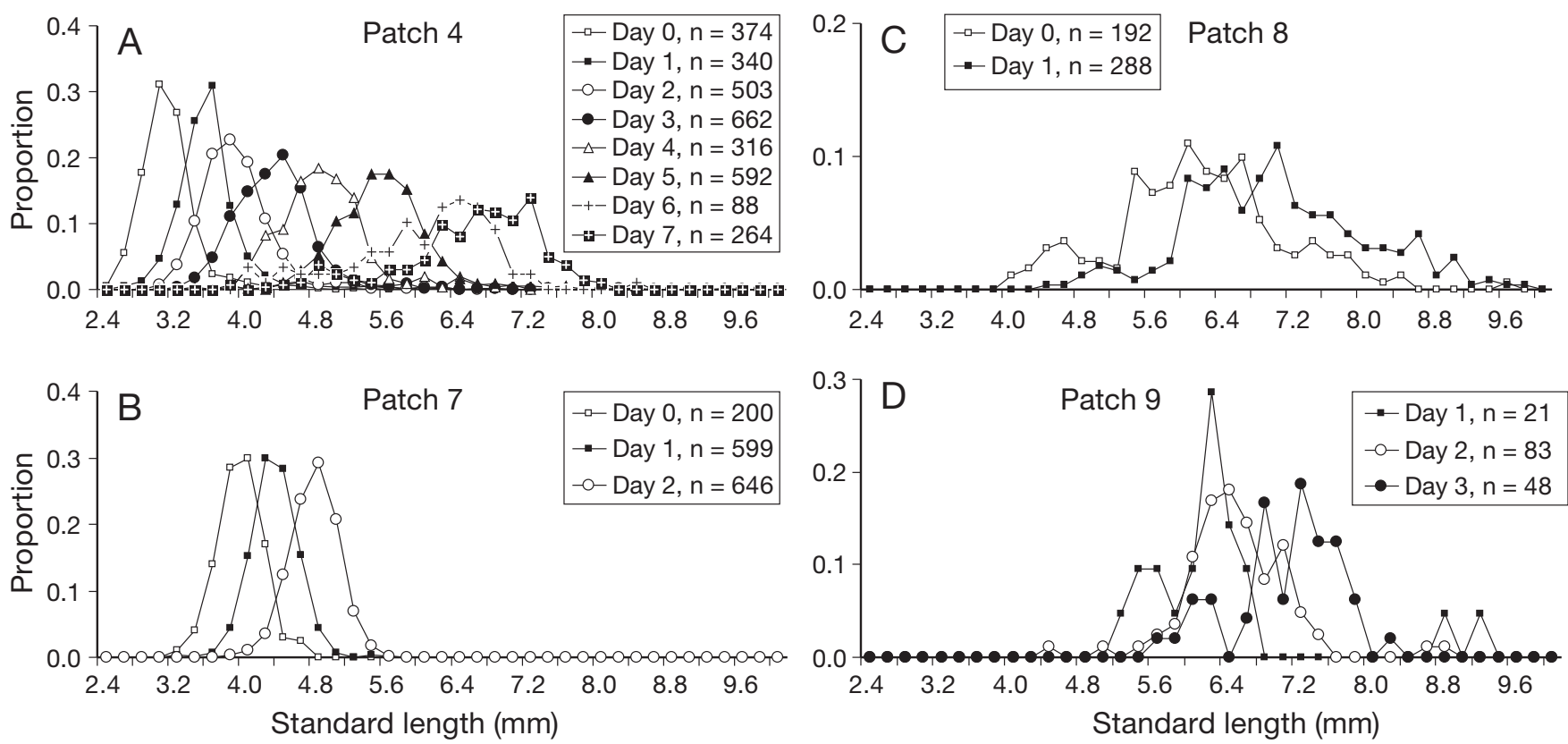

Fig. 2. Thunnus orientalis. Daily changes in the distribution of larval standard length on each tracking day of Patches (A) 4, (B) 7, (C) 8 and (D) 9. Tracking days $2(n=4)$ and $0(n=7)$ in $(C)$ and (D), respectively, are not shown due to small sample size 
Table 2. Thunnus orientalis. Otolith daily ring analysis. Growth rates $\left(\mathrm{mm} \mathrm{d}^{-1}\right)$ of each day after hatch (DAH) and medians, 10th and 90th percentiles and each quartile of standard length

\begin{tabular}{|lccccccc|}
\hline DAH & $\begin{array}{c}\text { Growth } \\
\text { rate }\end{array}$ & Median & $\begin{array}{c}\text { 10th } \\
\text { percentile }\end{array}$ & $\begin{array}{c}25 \% \\
\text { Q1 }\end{array}$ & $\begin{array}{c}75 \% \\
\text { Q3 }\end{array}$ & $\begin{array}{c}\text { 90th } \\
\text { percentile }\end{array}$ & $\mathrm{n}$ \\
\hline 4 & 0.29 & 3.76 & 3.29 & 3.49 & 4.13 & 4.33 & 91 \\
5 & 0.35 & 4.05 & 3.66 & 3.80 & 4.25 & 4.50 & 165 \\
6 & 0.42 & 4.40 & 4.01 & 4.20 & 4.64 & 4.85 & 264 \\
7 & 0.39 & 4.82 & 4.43 & 4.60 & 5.10 & 5.33 & 211 \\
8 & 0.41 & 5.21 & 4.81 & 5.00 & 5.53 & 5.80 & 154 \\
9 & 0.38 & 5.62 & 5.10 & 5.40 & 5.90 & 6.24 & 243 \\
10 & 0.40 & 6.00 & 5.40 & 5.70 & 6.27 & 6.58 & 325 \\
11 & 0.85 & 6.40 & 5.70 & 6.03 & 6.74 & 7.06 & 147 \\
12 & 0.25 & 7.25 & 6.40 & 6.90 & 7.52 & 7.62 & 84 \\
13 & 0.45 & 7.50 & 6.45 & 7.09 & 7.86 & 8.14 & 45 \\
14 & 0.35 & 7.95 & 7.00 & 7.69 & 8.51 & 8.88 & 22 \\
15 & 0.44 & 8.30 & 7.75 & 7.90 & 8.92 & 9.10 & 11 \\
16 & 0.42 & 8.74 & 8.22 & 8.39 & 9.00 & 9.46 & 7 \\
17 & & 9.16 & 7.84 & 8.28 & 9.62 & 9.88 & 7 \\
\hline
\end{tabular}
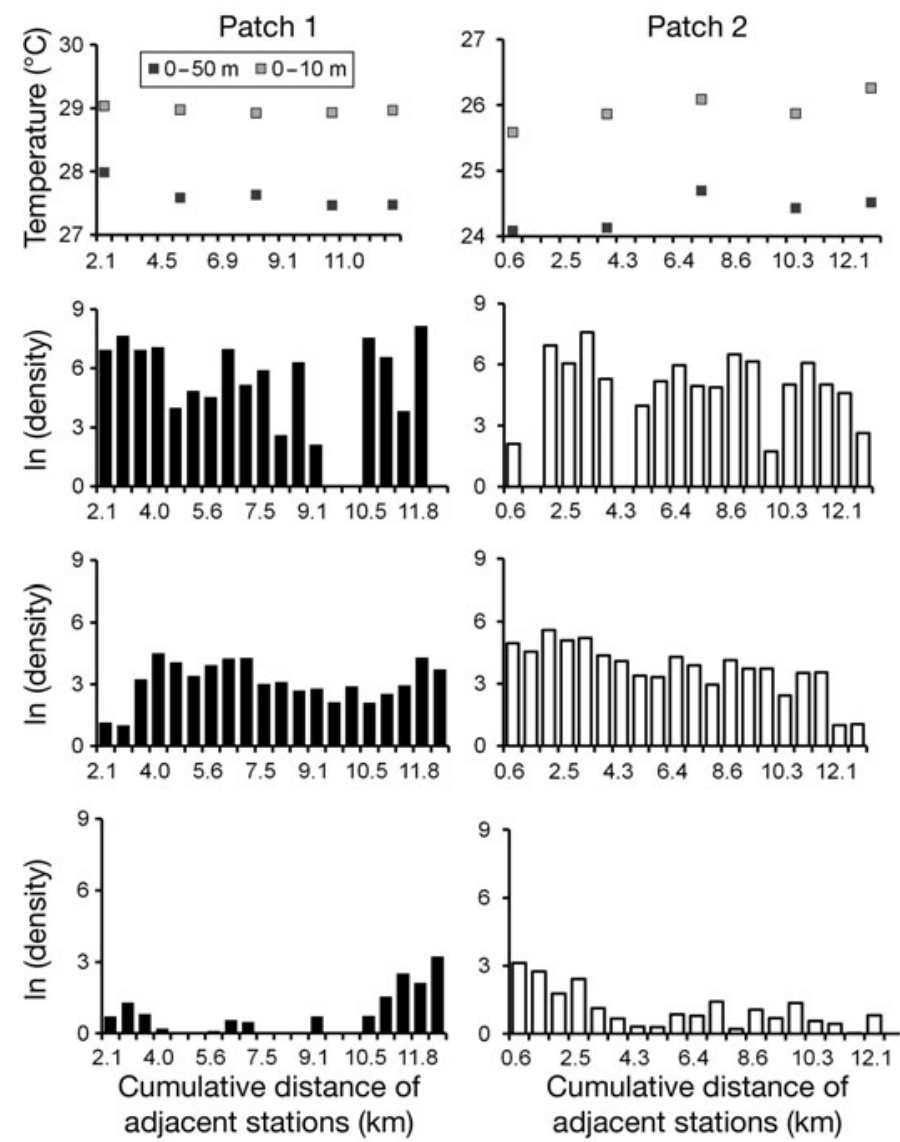

Fig. 3. Thunnus orientalis. Changes in sea temperature of Patches 1 and 2 ( $\square$ : average from 0 to $50 \mathrm{~m}$ depth; $\square$ : average from 0 to $10 \mathrm{~m}$ depth) at every 5 th station. Also shown is the distribution of larval densities $\left(\ln [\right.$ density +1$\left.] \times 1000 \mathrm{~m}^{-3}\right)$ at 6 , 9 and $12 \mathrm{~d}$ after hatch (DAH) for Patches 1 (solid bars) and 2 (white bars) of each station relative to cumulative distance of the adjacent stations throughout the sampling lines except for the 12 DAH cohort in Patch 1. Each cohort had different peak locations and different maximum larval densities. In addition, there was no clear relationship between the changes in larval density and sea temperature for each cohort.

The fine-scale spatial structure of larval density was also studied using variograms. The theoretical variogram model was not very well-fitted (high GOF) to the experimental variogram when the percentage of negative stations was relatively high $(5,6,13$ and 14 DAH, Patch 1, and >14 DAH, Patch 2; Tables S1 \& S2). Exceptionally, although the percentage of $8 \mathrm{DAH}$ in Patch 2 was $0 \%$, the GOF of this cohort was relatively high. The well-fitted (relatively low GOF and small range) cohorts which are indicated with asterisks in Table $\mathrm{S} 2$ are discussed further. In Patch 1, of the 6 available cohorts, 2 fitted best with a spherical model and 4 with a Gaussian model. In Patch 2, of the 8 cohorts, 1 fitted best with a spherical model, and 2 and 5 with a exponential and Gaussian model, respectively (Table S2, Fig. 4). The GOFs of Patch 1 (mean $=0.0328 \pm 0.0201$ ) were significantly smaller (generalized linear model [GLM], $F=8.86, \mathrm{p}=$ 0.0309; Table S3) than Patch 2 (0.0896 \pm 0.0439$)$. For the age-specific sill, range and spatial dependence (1 nugget/sill), there were no significant differences between the 2 patches (Table S3).

\section{Daily changes in larval distribution}

In the surface tows of the tracking experiments, 82 cohorts were tracked over 233 cumulative tracking days. The age-specific experimental variograms were fitted by modeled variograms for each patch (Table S2). The small number of stations on each tracking day resulted in a poor fit, especially in Patches 7, 8 and $9 ;$ therefore, further analysis was applied to Patches 3 and 4 .

In Patch 3, of the 10 available experimental variograms, 6 fitted best with a spherical, 2 with an exponential and 2 with a Gaussian model. The range did not show any trend with DAH and tracking day (Table S2, Fig. 5). The spatial dependence approximated 1, whereas the sill slightly decreased with DAH and tracking day and the GOF decreased remarkably with tracking day for every cohort. The GLM analysis, which considered DAH and tracking day as experimental variables, revealed that the GOF was strongly 

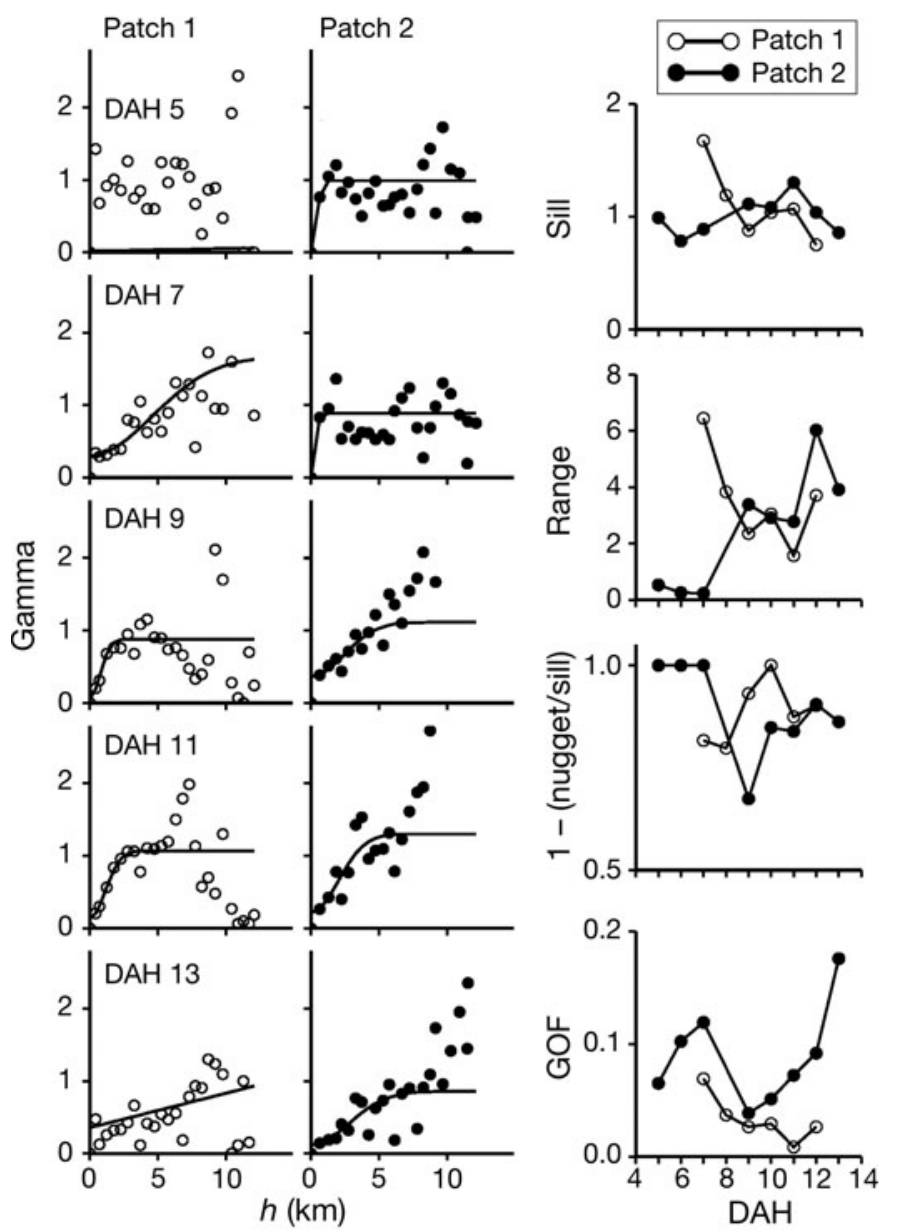

Fig. 4. Relative (to sample variance) experimental (O: Patch 1; -: Patch 2) and modeled variograms (-) for each day after hatch (DAH) of Patches 1 (left panels) and 2 (middle panels) on Tracking day $0 . h$ : distance between stations $(\mathrm{km})$. Righthand panels show age-specific values of sill, range, spatial dependence (1 - [nugget/sill]) and goodness-of-fit (GOF) of Patches $1(\mathrm{O})$ and $2(\bullet)$. Lag $=0.5 \pm 0.25 \mathrm{~km}$. Each fit used experiment variograms $<6 \mathrm{~km}$ (approximately half maximum $h$ ). Several points of experimental variograms of ages 9 and 11 in Patch 2 were larger than the $x$-axis range

affected by tracking day $(F=34.41, \mathrm{p}=0.0099$; Table S3), whereas there were no significant differences for the other indicators (range, sill and spatial dependence). Kriged maps were produced for each DAH on each tracking day (Fig. 6). The horizontal larval distributions were similar between successive DAH on the same tracking day than those of the same cohort on successive days. This is partly because the buoys cannot locate the same place within a patch due to the discrepancies mentioned below (see 'Discussion'). The values of environmental parameters and their variances during the tracking did not change remarkably except for food density (Fig. 7), of which the standard deviation drastically increased on Tracking day 2.
In Patch 4, the GOF was high (mean $=1.094 \pm 3.431$ ) and of 83 experimental variograms, only 19 (0.12 to 0.25 GOF) (13 fitted best with a spherical, 4 with an exponential and 2 with a Gaussian model) were subjected to further statistical analysis (Table S2, Figs. 8 \& S3). Although the effect of tracking day on the range and spatial dependence was close to 0.05 ( $p=0.0548$ and 0.0633 , respectively), not all parameters were significantly different between DAH and tracking days (Table S3). Except for salinity, other environmental conditions and variance changed after tracking day 3 (Fig. 7).

For the oblique tows (data not shown), 39 cohorts were tracked over 129 cumulative tracking days and 58 experimental variograms were obtained ${ }_{i}$ however, it was difficult to model appropriately because the number of stations was, in general, small compared to that of the surface tows. There were no consistent trends in model choice throughout the variogram analyses.

\section{Large-scale distribution}

The results of the schematic grid observation in June 2006 indicated that there were 2 patches (Patches 5 and 6 ) on the edge of 2 mesoscale eddies which propagated westward (Fig. 9A-C): a cyclonic and an anticyclonic eddy centered on the northeast and southwest side of the observation area, respectively. Patch 5 detected at Stn 146 consisted of 6 to 8 DAH larvae, and Patch 6 at Stn 152 consisted of 5 to 7 DAH larvae. The distance between the 2 stations was $65 \mathrm{~km}$ (Fig. 10). The velocities, salinities and temperatures at the 2 stations were relatively high, low and average, respectively. Although the salinities were low at Stns 138, 140 and 141, there were no occurrences of tuna larvae. There was no clear relationship between the occurrence of patches and ambient temperature and salinity.

Regarding the oblique tows, the fit for the experimental variograms was generally not good (Table S4, Fig. 11); experimental variograms on the first lag (origin to $15 \mathrm{~km}$ ) were approximately zero, and those of the second lags (15 to $30 \mathrm{~km}$ ) were not obtained, and after the third lags $(>30 \mathrm{~km})$ they were close to the value of the sill. Therefore, the range could be distributed in the first or second lag if the range exists. On the other hand, for the surface tows, the numbers of experimental variograms on the first and second lags were appropriate for the variogram analysis; therefore, the theoretical models of each DAH were obtained. The ranges for surface tows were distributed from 2.2 to $6.3 \mathrm{~km}$. Of the 8 available cohorts, 6 fitted best with an exponential model and 2 with a Gaussian model (Table S4). None of the indicators of spatial structure 

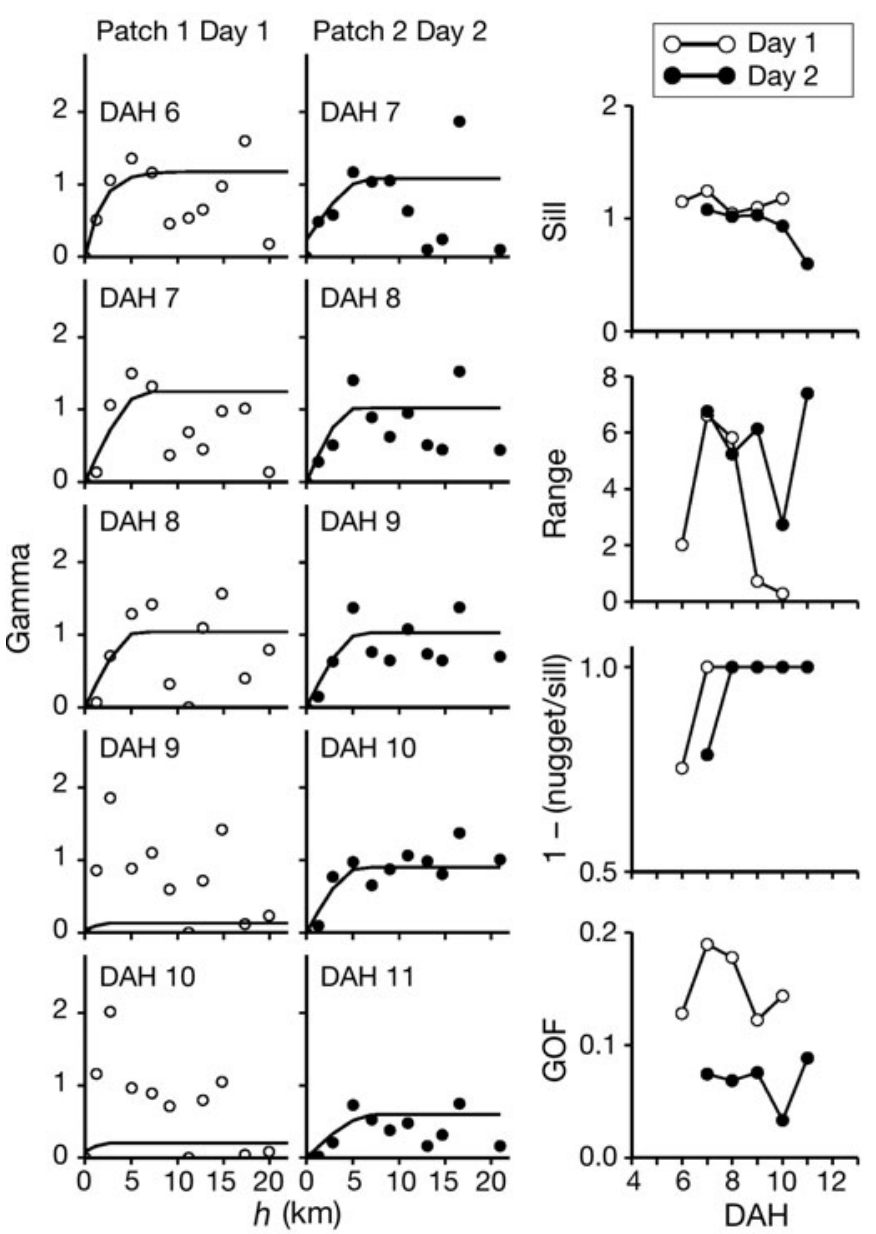

Fig. 5. Relative (to sample variance) experimental (O: Tracking day $1 ; \bullet$ : Tracking day 2) and modeled variograms (-) for each day after hatch (DAH) of Patch 3 on Tracking days 1 (left panels) and 2 (middle panels). Right-hand panels show age-specific values of sill, range, spatial dependence (1 [nugget/sill]) and goodness-of-fit (GOF) of Patches 1 (O) and 2 $(\bullet)$. $h$ : distance between stations $(\mathrm{km})$. Lag $=2.0 \pm 1.0 \mathrm{~km}$. Each fit used all experimental variograms (maximum distance is approximately $22 \mathrm{~km}$ )

showed significant differences between DAH or towing method (Table S3).

\section{Vertical distribution}

The specific layer horizontal tows were conducted from 12:00 h, 2 June 2005 to 08:00 h, 4 June 2005 every $4 \mathrm{~h}$ at 10 stations near the reference buoys (Fig. 12). The larval densities of the $0 \mathrm{~m}$ depth layer were substituted for that of the $2 \mathrm{~m}$ ring net. Tuna larvae were collected in the layer shallower than $20 \mathrm{~m}$. The depth of the bottom of the mixed layer was estimated at about $40 \mathrm{~m}$ depth both at the first (M13) and the last station (M22). Copepods were collected in almost all layers.
Patch 3, Tracking day 1 Patch 3, Tracking day 2

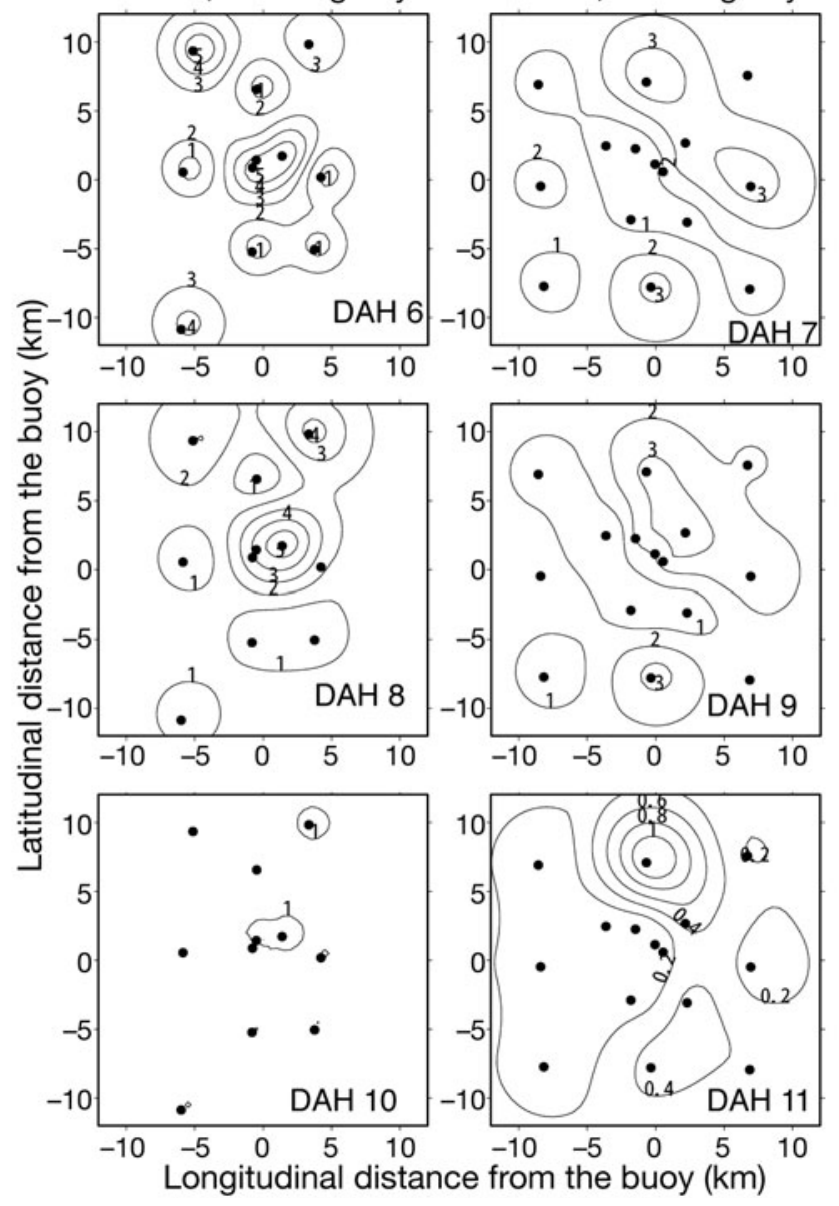

Fig. 6. Thunnus orientalis. Larval density $(\ln [$ density +1$] \times$ $1000 \mathrm{~m}^{-3}$ ) distributions of each day after hatch (DAH) of Patch 3 on Tracking days 1 (left panels) and 2 (right panels) as derived by ordinary kriging. The origin is the position of the reference buoy, and the $x$ - and $y$-axes are longitudinal and latitudinal distance $(\mathrm{km})$ from the buoy, respectively

\section{DISCUSSION}

\section{Tracking}

The distributions of velocities and directions of sea surface currents measured from ADCP and buoy trajectories resembled each other, although the distribution of velocity of Patch 4 calculated from the buoy trajectory was skewed left (Fig. S1). In Patches 2 and 8, the disagreement between the directions of geostrophic current and the buoy trajectories is considered to result from other effects such as wind, which becomes relatively more important in areas affected by weak geostrophic currents. The depth of water under all tracking routes was in excess of $1000 \mathrm{~m}$ (Fig. 1). Therefore, the effects of bottom depth and tides on the surface currents is limited. Although discrepancies be- 

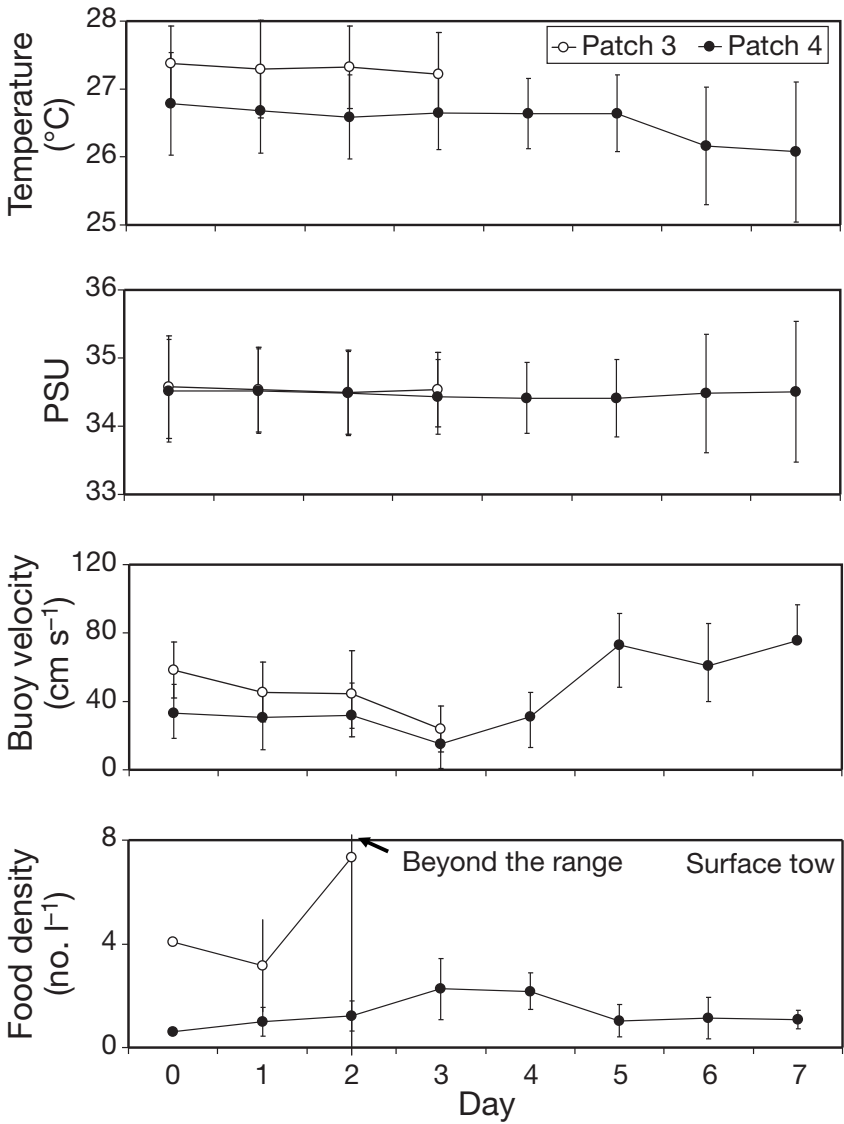

Fig. 7. Daily changes in temperature $\left({ }^{\circ} \mathrm{C}_{i}\right.$ average from 0 to $50 \mathrm{~m}$ depth), salinity, surface velocity derived from buoy trajectory $\left(\mathrm{cm} \mathrm{s}^{-1}\right)$ and food density (no. $\mathrm{l}^{-1}$ ) for surface tows during tracking for Patches 3 and 4. Error bars are standard deviation

tween trajectories of water mass and drogues inevitably occur (Fortier \& Leggett 1985, Chereskin et al. 1989), growth rates estimated from the daily changing speed of the SL mode (Fig. 2) (Satoh et al. 2008) correspond to those of otolith daily ring analysis (Table 2). These results indicate that the same population of the 7 patches was sampled during tracking except for Tracking day 2 of Patch 8.

\section{Horizontal and vertical distribution}

In the fine- and mid-scale observations, each patch consisted of a number of cohorts which had different peak locations to each other. This might have resulted from a mixture of cohorts due to the dispersal of larvae originating from different spawning events. The magnitude of the horizontal range of the hatched larvae varied case by case and depends on the number of the spawning fish in the spawning event. The possibility of mixture of cohorts from different spawning events cannot be ruled out. However, clear daily changes in SL

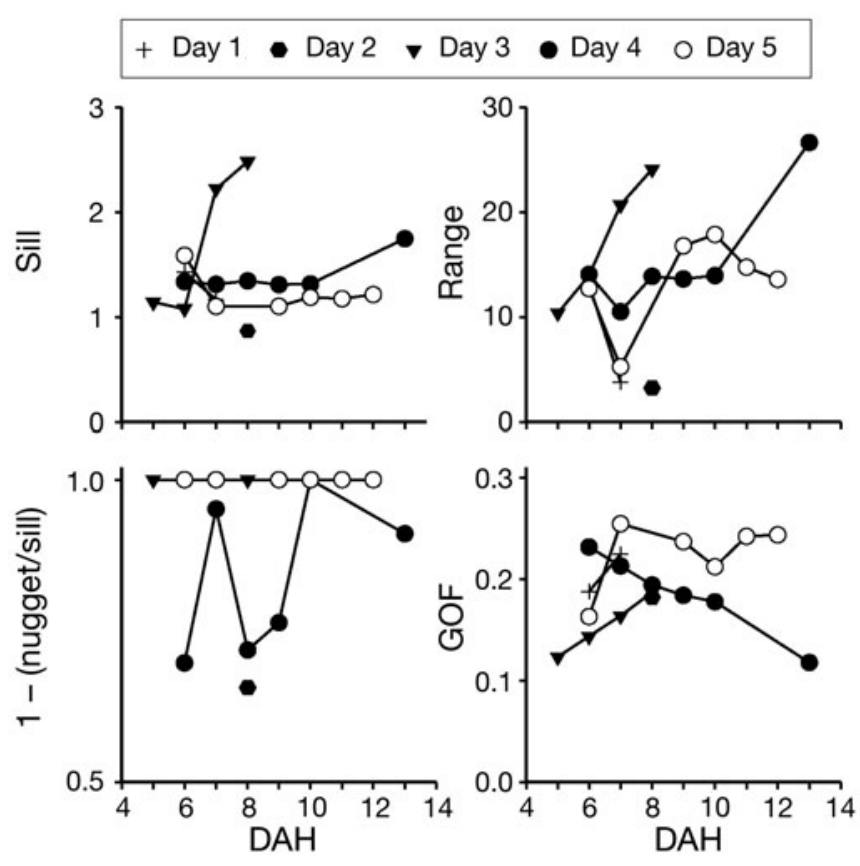

Fig. 8. Surface tows. Age-specific values (days after hatch, DAH) of sill, range, spatial dependence (1 - [nugget/sill]) and goodness-of-fit (GOF) of Patch 4 from Tracking day 1 to 5 . The values of all ages on Tracking days 0, 6 and 7 were omitted because these model variograms did not fit well

distribution during trackings within the mid scale were observed (Fig. 2) (Satoh et al. 2008). The result that each patch consisted of a number of cohorts also indicates that the spawning events occur repeatedly within the mid scale over some duration. A patch of southern bluefin tuna larvae was found also to consist of a number of ages (9 and 10 d) (Davis et al. 1990a).

In some patches $(1,2,3,5$ and 6$)$, the theoretical variograms were relatively well fitted to the experimental variograms (Figs. $4 \& 5$ ). The results indicate that the kriging method is appropriate to understand the larval spatial distribution. Unfortunately, the sampling strategy was not well designed for using this method, the small number observations in other patches $(4,7,8$ and 9) resulted in poor fitting (e.g. Fig. S3) and information about horizontal distribution could not readily determined.

After fertilization, the horizontal spatial structure of a cohort is affected by biotic and abiotic conditions such as the amount of predators, competitors for food, density of food organisms, sea temperature and diffusion rate. Large variation in these factors among stations will result in large fluctuations of larval density among stations, and thus lead to a contraction in range and increase in sill. Indeed, small variations in environmental conditions were generally observed. There is no clear evidence for the relationship between environmental 

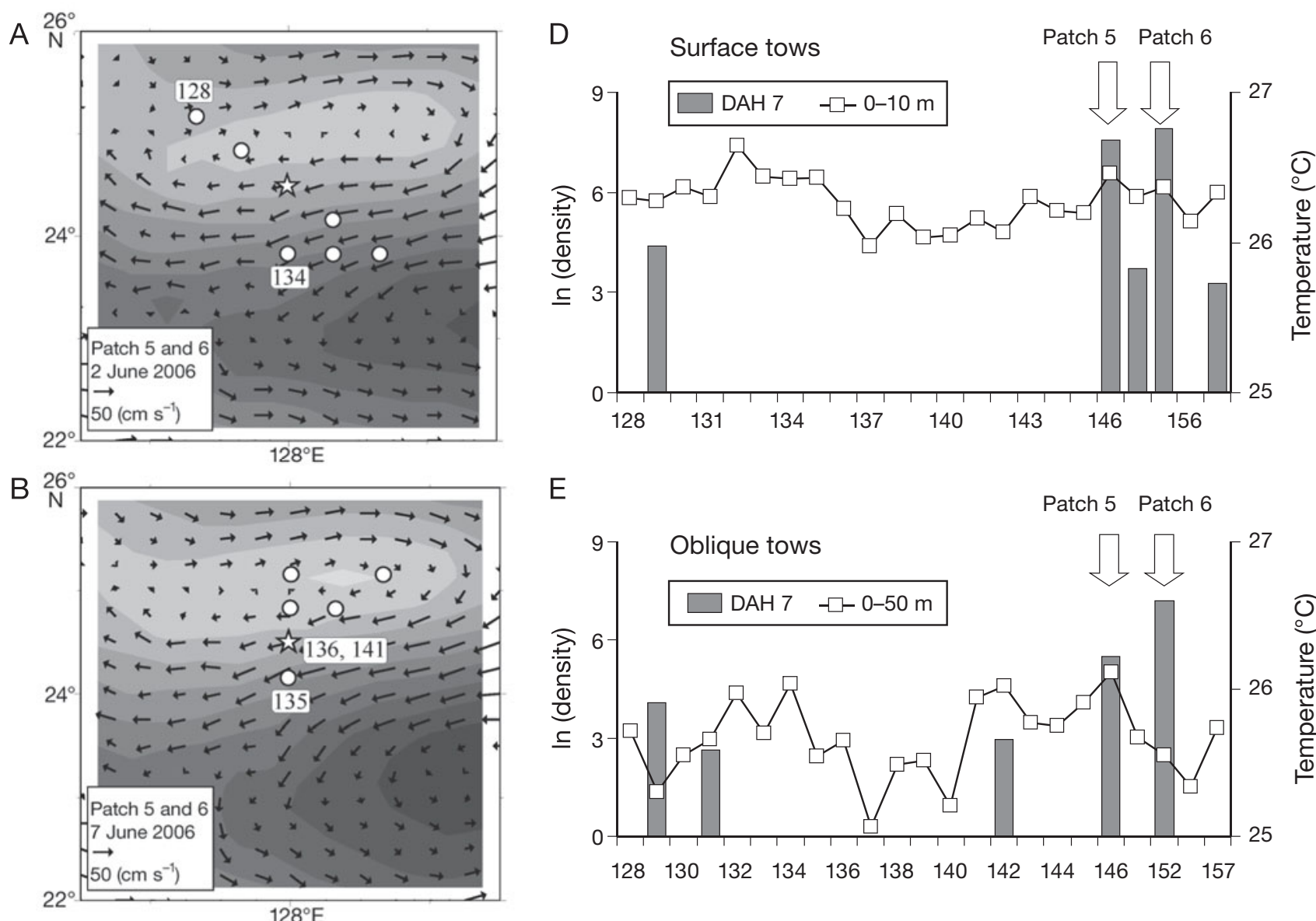

$E$

Patch 5 Patch 6

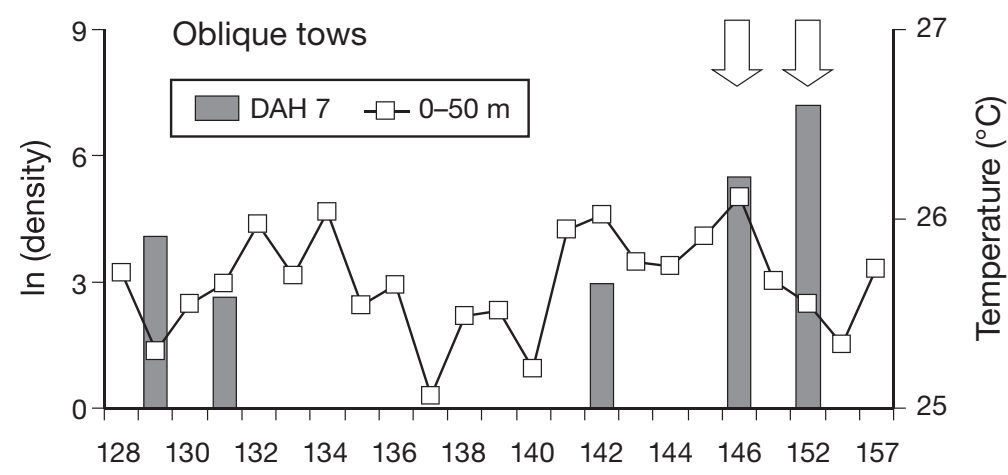

F
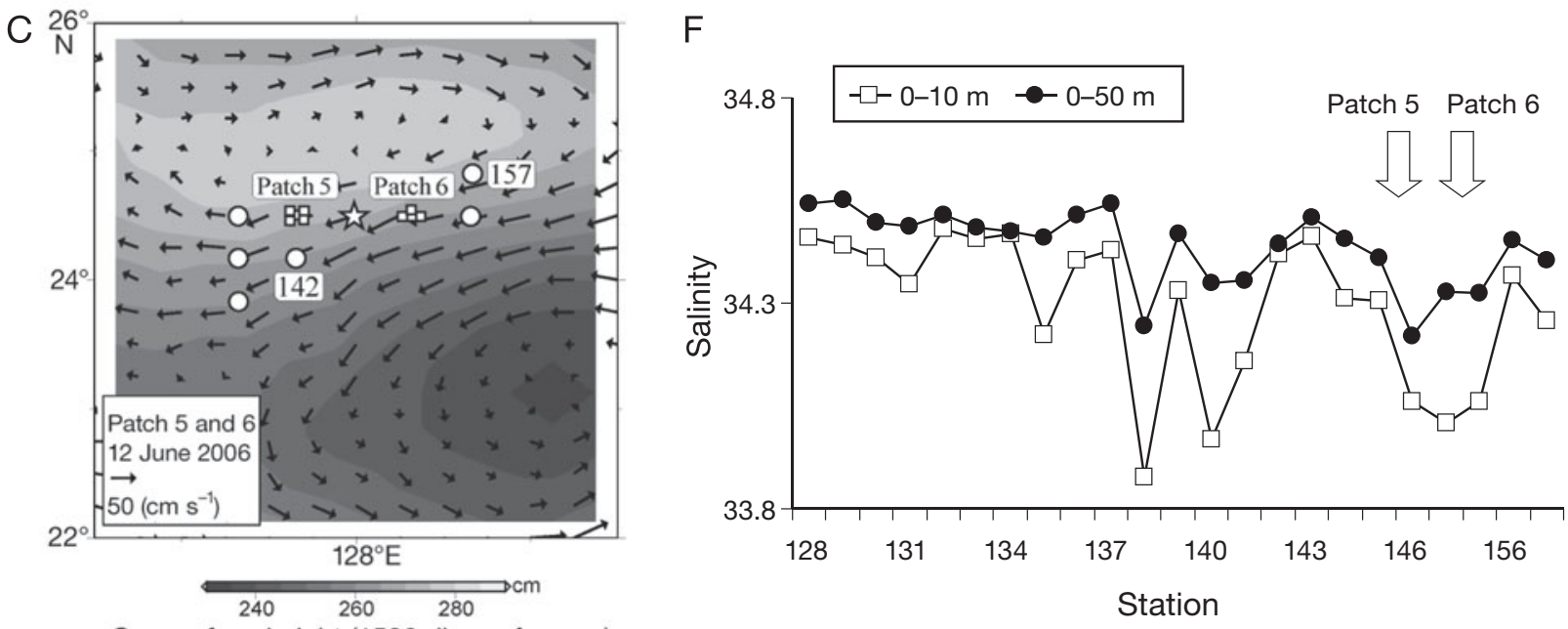

Sea surface height (1500 dbar reference)

Fig. 9. Thunnus orientalis. Large-scale larval distribution. (A-C) Sea surface height, sea surface currents and stations (nos. next to symbols - O station nos.; s station at the center of the schematic observation) in June 2006. Patches 5 and 6 were detected at Stns 146 and 151, respectively. (D,E) Larval density (ln[density +1$] \times 1000 \mathrm{~m}^{-3}$ ) and temperature for (D) surface tows, (E) oblique tows, (F) mean salinity

conditions and larval spatial structure. However, paradoxically, the small variation in the environmental factors could result in the stability of the spatial structure investigated through variograms during trackings.
Additionally, models were not well-fitted after Tracking day 6 in Patch 4, where some environmental factors showed large variations among stations even as the percentage of negative collection station decreased. 


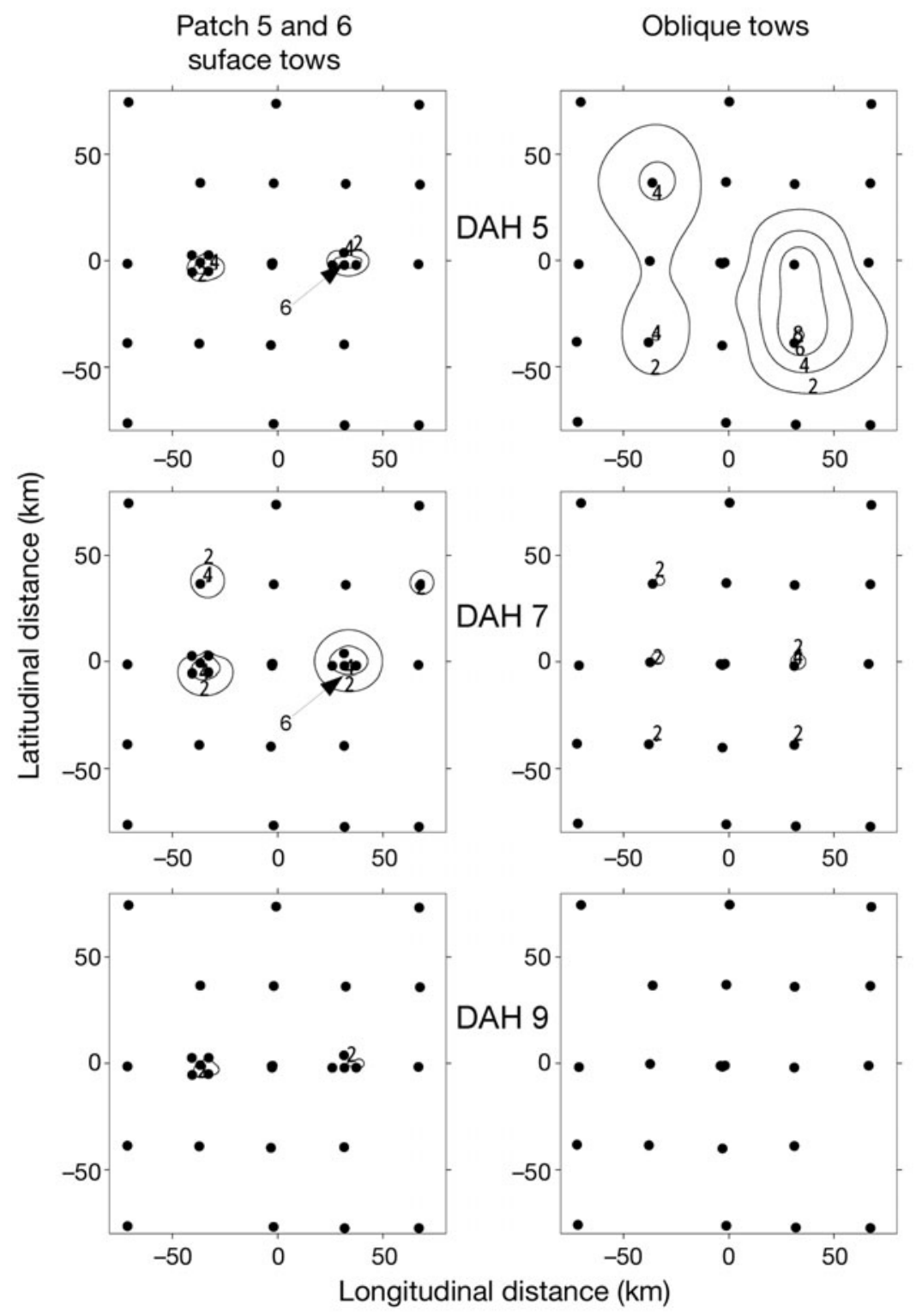

Fig. 10. Thunnus orientalis. Larval density $\left(\ln [\right.$ density +1$\left.] \times 1000 \mathrm{~m}^{-3}\right)$ distributions of each day after hatch (DAH) on observation of 30 (surface tows, left panels) and 23 (oblique tows, right panels) stations in June 2006, including Patches 5 and 6, as derived by ordinary kriging. The origin is the position of Stn 130, which is located in the center of the survey area in June 2006, and the $x$ - and $y$-axes show longitudinal and latitudinal distance from the center position, respectively gate within a small scale (several $\mathrm{m}$ to $10 \mathrm{~m})$.

The values of the sill and range easily changed if the lag spacing varied. In the present study, the lack of consistency in lag spacing for each scale (finescale: lag $=0.5 \mathrm{~km}$; mid-scale: lag $=$ $2.0 \mathrm{~km}$; large-scale: $\mathrm{lag}=8$ and $15 \mathrm{~km}$ ) reflected the differences in the distance between stations. Therefore, the location of a sampling station will strongly affect the results. The location of sampling stations in the present study relative to the buoy or to the center station of the survey area also showed no consistency among sampling day. Therefore, in general, indices derived from variogram analyses with different scales are not readily comparable. Even so, it is notable that there is similarity in the estimated range, several $\mathrm{km}$ to $30 \mathrm{~km}$, among different scales, especially at a scale of $<10 \mathrm{~km}$. The range is the area unit for a station with a high self-correlation, therefore it is not equal to the larval distribution area. However, the range value (several $\mathrm{km}$ to $30 \mathrm{~km}$ ) resembles the spatial range of $\sim 5$ to $15 \mathrm{~km}$ of southern bluefin tuna larvae (Davis et al. 1990b). Thus, when the environmental conditions are stable, the spatial structure of the larval population also shows stability; horizontally, larvae form patches of approximately several to $30 \mathrm{~km}$ and advect together during the larval stage. There might be some physical constraints that make larvae form patches of this size. In addition, the sustainability of the structure suggests that spawning events of bluefin tuna also occur on a $10 \mathrm{~km}$ scale. The spatial range also shows that the station distance of the trial tows $(\sim 8$ to $9 \mathrm{~km})$ is appropriate to detect patches.

This result also suggests that fluctuations in environmental conditions would affect larval spatial structure.

In general, the spatial dependences (1 - nugget/sill) were close to 1.0 because nuggets tended to be near zero. The nuggets represent microscale variations which are comparable to the very fine-scale distribution within one path of the $2 \mathrm{~m}$ ring plankton net, approximately $2 \mathrm{~m}$ diameter by $250 \mathrm{~m}$ long for a surface tow of $5 \mathrm{~min}$. The results of nugget (near zero) might indicate that the larvae are not likely to aggre-
In the large-scale observations, the ranges $(2.2$ to $6.3 \mathrm{~km}$ ) were smaller than the distance between stations $(65 \mathrm{~km})$, which may suggest that 2 patches (5 and The distributions of dominant larval ages of Patches 5 and 6 were 4 to 9 and 5 to $8 \mathrm{DAH}$, respectively, which also indicates that different spawning events occurred on a similar spatiotemporal scale. The environmental factors (temperature and salinity) for Patches 5 and 6 were similar to each other; however, larvae did not 6 ) should be considered as different larval populations. 

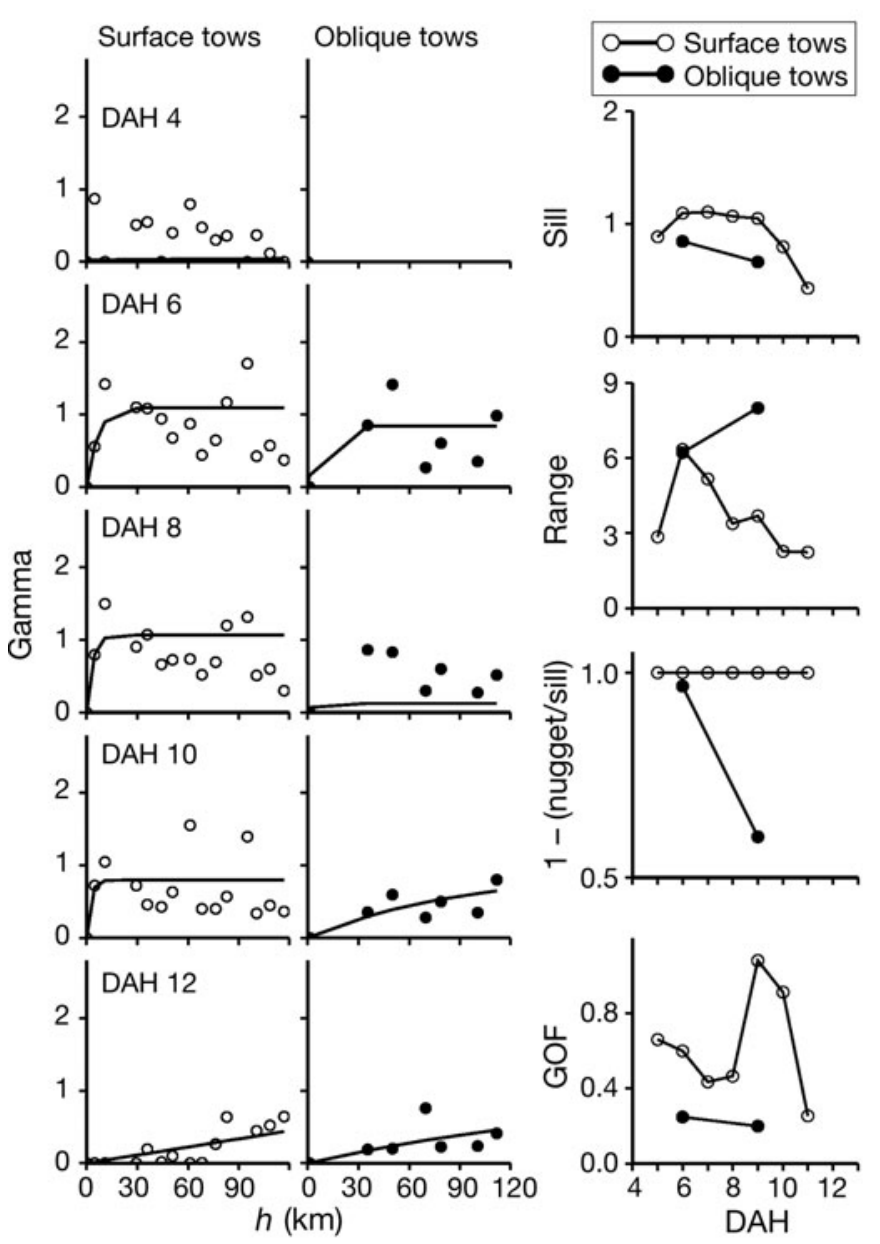

Fig. 11. Relative (to sample variance) experimental variograms of observation of 30 (o: surface tows) and 23 ( $\bullet$ : oblique tows) stations in June 2006, including Patches 5 and 6 . $h$ : distance between stations $(\mathrm{km})$. Lag $=8.0 \pm 4.0 \mathrm{~km}$ for surface tows, $15.0 \pm 7.5 \mathrm{~km}$ for oblique tows. Each fit used variograms $<50 \mathrm{~km}$ (approximately half of maximum $h$ ) for surface tows and all experiment variograms for oblique tows

occur in many stations with similar environmental conditions to those of stations in Patches 5 and 6 (Fig. 9). Patches 5 and 6 were located in relatively strong currents, and the current velocities of the detected stations in Patches 1, 3, 4, 7 and 9 were also relatively high; however, the remaining 2 patches (2 and 8 ) occurred in areas of weak currents (Figs. S1 \& S2). Therefore, it is difficult to predict the existence of a patch with any of the 3 environmental factors (temperature, salinity and surface current velocity).

Pacific bluefin tuna larvae occurred only in the mixed layer. The absence of larvae below the mixed layer is partially due to the strong pycnocline. However, this may be mainly due to species-specific features, e.g. that bluefin tuna larvae tend to be distributed in the upper layer of the water column. Many studies have reported that other tuna species larvae tend to distribute in the mixed layer, near the surface (Matsumoto 1958, Strasburg 1960, Ueyanagi 1969, Davis et al. 1990b, Boehlert \& Mundy 1994). This larval distribution in the mixed layer might be one of the reasons why bluefin tuna larvae were collected continuously in the mid scale for several days to a week; the narrow range of the vertical distribution resulted in the same environmental shear in the upper layer of the water column and also supports the horizontal stability of spatial structure during advection of larval stage.

Diel vertical movement of bluefin tuna larvae was not observed clearly. The diel movement patterns of the larvae of other tuna species have been variously reported. Southern bluefin tuna larvae moved into the surface layers during the day (Davis et al. 1990b), albacore larvae have been reported to show both vertical migration (Davis et al. 1990b) and no diel vertical movement (Ueyanagi 1969).

\section{Role of mesoscale eddies and the Kuroshio}

The patches composed of a number of cohorts were entrained in mesoscale eddies, which propagate westward at a speed of about 7 to $10 \mathrm{~cm} \mathrm{~s}^{-1}$, some of which coalesce with the Kuroshio Current (Ebuchi \& Hanawa 2001). Thus, a cohort which is trapped and entrained by a mesoscale eddy is more likely to enter the Kuroshio. After 2 or 3 mo of the spawning season, the bluefin tuna grow to about $30 \mathrm{~cm}$ SL and recruit to the troll fisheries near the coast of islands located north of the spawning grounds off the Nansei Islands. The spawning area and the fishing grounds are linked by the Kuroshio (Fig. 1). The larvae are widely distributed in the spawning area as well as in the Kuroshio (Nishikawa et al. 1985). On the other hand, juveniles are collected only in the Kuroshio before recruitment; for example, 174 early juveniles (mean $\pm \mathrm{SD}=32.2 \pm$ $3.4 \mathrm{~mm}$ SL) were collected in June 1997 (Tsuji et al. 1999). Although this is indirect evidence, results indicate that juveniles could utilize the Kuroshio as one of the routes of migration to the coast of Japanese islands. Although poor swimmers, larvae and early juveniles are likely to be able to successfully complete the migration to the more eutrophic area off the coast of southern Japanese islands if they utilize the combination of westward propagating eddies and the Kuroshio.

Results from the present study suggest that the spatial structure of a cohort is stable after fertilization, during advection and while entrained in mesoscale eddies. Therefore, the positional relationship between spawning events and mesoscale eddies is concluded to be important for the recruitment process of Pacific bluefin tuna. 

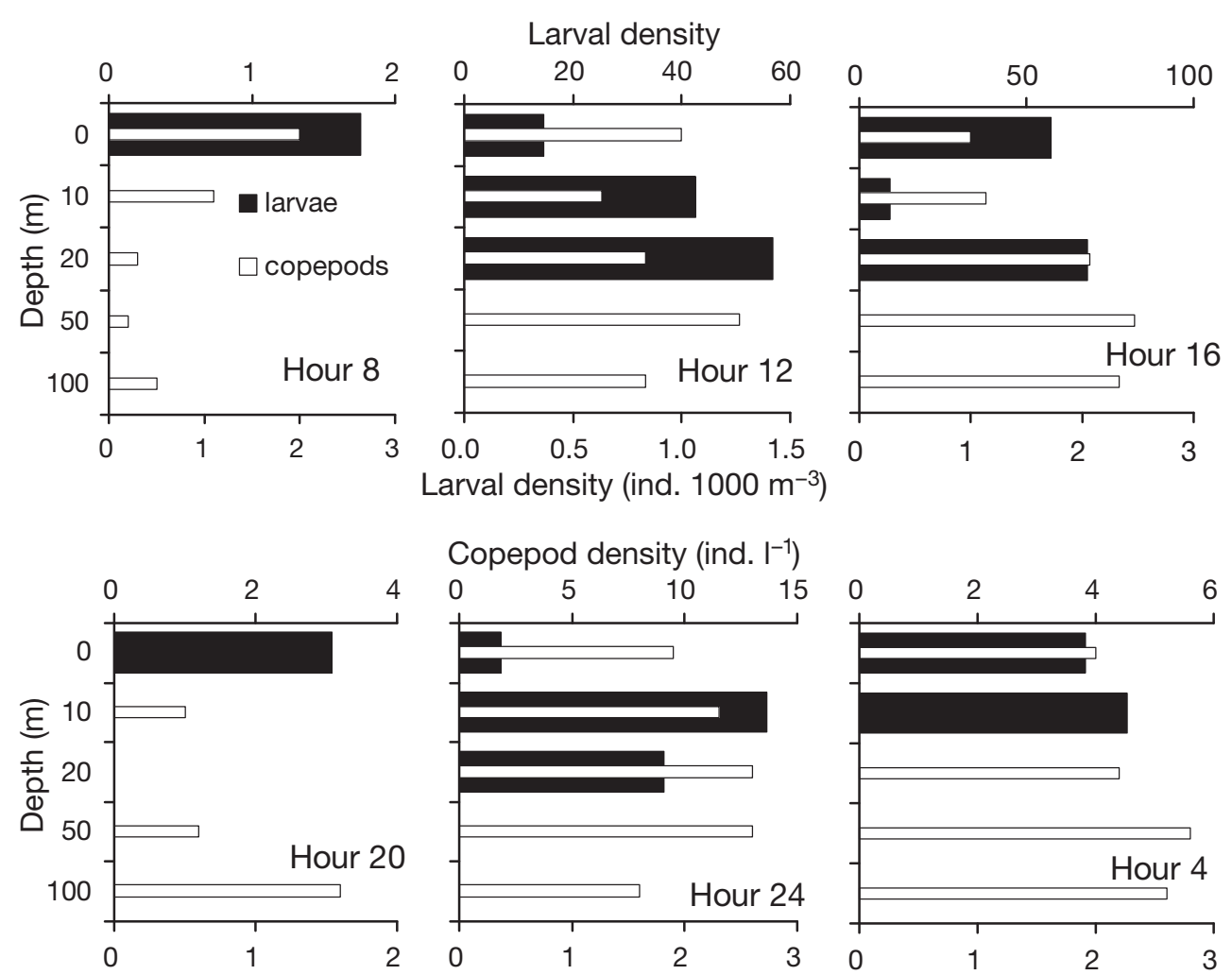

Copepod density (ind. $\mathrm{I}^{-1}$ )
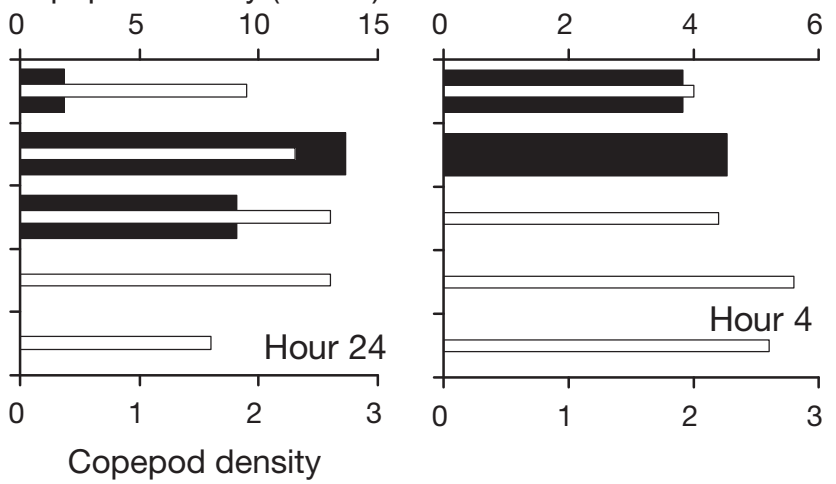

Sigma-t

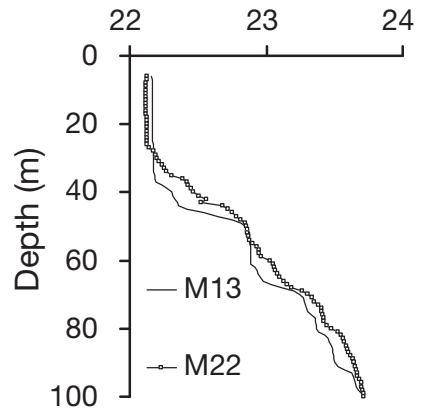

Fig. 12. Thunnus orientalis. Vertical larval distribution (black bars; ind. $\times 1000 \mathrm{~m}^{-3}$ ) and copepod density (white bars; ind. $\mathrm{l}^{-1}$ ) of each layer $(0,10,20,50$ and $100 \mathrm{~m}$ depth) for every $4 \mathrm{~h}$ of Patch 3 in June 2005. Larval densities are not corrected for net avoidance, net intrusion or sampling time. Vertical profiles of sigma-t and temperature of the first (Stn M13) and last (Stn M22) station

of the MOCNESS observations

Acknowledgements. I especially thank Captain Y. Terada (2008) and former Captain M. Onoda (2004-2007) and crew of the RV 'Shunyo-Maru' for their suggestions and constant support. I thank K. Hiramoto, Y. Tanaka, M. Yamada, K. Murai, K. Korenaga, T. Urushizaka, E. Asakawa, M. Tanikawa, K. Nishimura, M. Suda, K. Hoshino and N. Chow for their support on deck. I am grateful to Y. Tanaka, M. Suda, S. Nara, H. Asai, Y. Takahashi, M. Tanikawa and K. Hoshino for their help in sorting and identifying ichthyoplankton species. I also thank Z. Suzuki, M. Miyabe, H. Honda, H. Okamoto, H. Shono, C. Norman and M. Masujima for suggesting many improvements to the manuscript.

\section{LITERATURE CITED}

Boehlert GW, Mundy BC (1994) Vertical and onshoreoffshore distributional patterns of tuna larvae in relation to physical habitat features. Mar Ecol Prog Ser 107:1-13

Chereskin TK, Niiler PP, Poulain PM (1989) A numerical study of the effects of upper-ocean shear on flexible drogued drifters. J Atmos Ocean Technol 6:243-253

Chihara M, Murano M (1997) An illustrated guide to marine plankton in Japan. Tokai University Press, Tokyo

Davis TLO, Jenkins GP, Young JW (1990a) Pattern of horizontal distribution of the larvae of southern bluefin tuna 
(Thunnus maccoyii) and other tuna in the Indian Ocean. J Plankton Res 12:1295-1314

Davis TLO, Jenkins GP, Young JW (1990b) Diel patterns of vertical distribution in larvae of southern bluefin Thunnus maccoyii, and other tuna in the East Indian Ocean. Mar Ecol Prog Ser 59:63-74

> Davis TLO, Lyne V, Jenkins GP (1991) Advection, dispersion and mortality of a patch of southern bluefin tuna larvae Thunnus maccoyii in the East Indian Ocean. Mar Ecol Prog Ser 73:33-45

Dower JF, Pepin P, Leggett WC (2002) Using patch studies to link mesoscale patterns of feeding and growth in larval fish to environmental variability. Fish Oceanogr 11: $219-232$

Ebuchi N, Hanawa K (2000) Mesoscale eddies observed by TOLEX-ADCP and TOPEX/POSEIDON altimeter in the Kuroshio recirculation region south of Japan. J Oceanogr 56:43-57

Ebuchi N, Hanawa K (2001) Trajectory of mesoscale eddies in the Kuroshio recirculation region. J Oceanogr 57:471-480

Fortier L, Leggett WC (1985) A drift study of larval fish survival. Mar Ecol Prog Ser 25:245-257

Heath MR (1992) Field investigations of the early life stages of marine fish. Adv Mar Biol 28:1-174

Houde ED (1987) Fish early life dynamics and recruitment variability. Am Fish Soc Symp 2:17-29

Itoh T, Shiina Y, Tsuji S, Endo F, Tezuka N (2000) Otolith daily increment formation in laboratory reared larval and juvenile bluefin tuna Thunnus thynnus. Fish Sci 66:834-839

Journel AG, Huijbregts CJ (1978) Mining geostatistics. Academic Press, London

Kamoshida T, Shimada K, Shinke T (2004) A method to improve data quality of shipboard ADCP mounted on R/V Mirai. Rep Jpn Mar Sci Technol Cent 49:33-41 (In Japanese)

Kuragano T, Kamachi M (2000) Global statistical spacetime scales of oceanic variability estimated from the TOPEX/POSEIDON altimeter data. J Geophys Res 105: 955-974

Kuragano T, Kamachi M (2003) Altimeters capability of reconstructing realistic eddy fields using space-time optimum interpolation. J Oceanogr 59:765-781

Kuragano T, Shibata A (1997) Sea surface dynamic height of the Pacific Ocean derived from TOPEX/POSEIDON altimeter data: calculation method and accuracy. J Oceanogr 53:585-599

Li X, Litvak MK, Clarke JEH (2007) Overwintering habitat use of shortnose sturgeon (Acipenser brevirostrum): defining critical habitat using a novel underwater video survey and modeling approach. Can J Fish Aquat Sci 64:1248-1257

Matsumoto WM (1958) Description and distribution of larvae of four species of tuna in central Pacific waters. Fish Bull $58: 31-72$

Miyashita S (2002) Studies on the seedling production of the Pacific bluefin tuna, Thunnus thynnus orientalis. Bull Fish Lab Kinki Univ 8:1-171

Editorial responsibility: Hans Heinrich Janssen, Oldendorf/Luhe, Germany
Nishikawa Y (1985) Identification for larvae of three species of genus Thunnus by melanophore patterns. Bull Far Seas Fish Res Lab 22:119-129

Nishikawa Y, Honma M, Ueyanagi S, Kikawa S (1985) Average distribution of larvae of oceanic species of scombrid fishes, 1956-1981. Bull Far Seas Fish Res Lab 12:1-99

Okiyama M (1974) Occurrence of the postlarvae of bluefin tuna, Thunnus thynnus, in the Japan Sea. Bull Jpn Sea Natl Fish Res Inst 25:89-97

Pepin P, Dower JF, Helbig JA, Leggett WC (2002) Estimating the relative roles of dispersion and predation in generating regional differences in mortality rates of larval radiated shanny (Ulvaria subbifurcata). Can J Fish Aquat Sci 59:105-114

R Development Core Team (2009) R: a language and environment for statistical computing. R Foundation for Statistical Computing, Vienna http://www.R-project.org

Rivoirard J, Simmonds J, Foote KG, Fernandes P, Bez N (2000) Geostatistics for estimating fish abundance. Blackwell Science, London

Satoh K, Tanaka Y, Iwahashi M (2008) Variations in the instantaneous mortality rate between larval patches of Pacific bluefin tuna Thunnus orientalis in the northwestern Pacific Ocean. Fish Res 89:248-256

Somerton DA, Kobayashi DR (1989) A method for correcting catches of fish larvae for the size selection of plankton nets. Fish Bull 87:447-455

Strasburg DW (1960) Estimates of larval tuna abundance in the central Pacific. Fish Bull 60:231-255

Tanaka Y, Satoh K, Iwahashi M, Yamada H (2006) Growthdependent recruitment of Pacific bluefin tuna Thunnus orientalis in the northwestern Pacific Ocean. Mar Ecol Prog Ser 319:225-235

Tsuji S, Itoh T, Inagake D, Kaji T and others (1999) Report of first research cruise of Shunyo-maru in 1997. National Institute of Far Seas Fisheries, Shimizu (In Japanese)

Ueyanagi S (1969) Observations on the distribution of tuna larvae in the Indo-Pacific Ocean with emphasis on the delineation of the spawning areas of albacore, Thunnus alalunga. Bull Far Seas Fish Res Lab 2:177-203 (In Japanese with English abstract)

Uotani I, Saito T, Hiranuma K, Nishikawa Y (1990) Feeding habit of bluefin tuna Thunnus thynnus larvae in the western North Pacific Ocean. Bull Jpn Soc Sci Fish 56: 713-717

Wiebe PJ, Burt KH, Boyd SH, Morton AW (1976) A multiple opening/closing net and environmental sensing system for sampling zooplankton. J Mar Res 34:313-326

Yabe H, Ueyanagi S, Watanabe H (1966) Studies on the early life history of bluefin tuna Thunnus thynnus and on the larvae of the southern bluefin tuna T. maccoyii. Rep Nankai Reg Fish Res Lab 23:95-129

Yamada H, Takagi N, Nishimura D (2006) Recruitment abundance index of Pacific bluefin tuna using fisheries data on juveniles. Fish Sci 72:333-341

Submitted: January 30, 2009; Accepted: November 24, 2010 Proofs received from author(s): March 19, 2010 